Required software to e-Annotate PDFs: Adobe Acrobat Professional or Adobe Reader (version 11 or above). (Note that this document uses screenshots from Adobe Reader DC.)

The latest version of Acrobat Reader can be downloaded for free at: http://get.adobe.com/reader/

Once you have Acrobat Reader open on your computer, click on the Comment tab (right-hand panel or under the Tools menu).

This will open up a ribbon panel at the top of the document. Using a tool will place a comment in the right-hand panel. The tools you will use for annotating your proof are shown below:

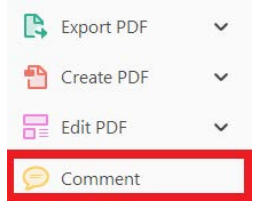

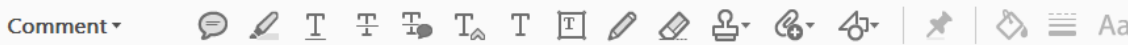

1. Replace (Ins) Tool - for replacing text.

T. Strikes a line through text and opens up a text box where replacement text can be entered.

How to use it:

- Highlight a word or sentence.

- Click on $T_{D}$.

- Type the replacement text into the blue box that appears.

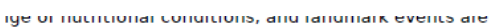
nitored in populations of relatively homogeneous single $\mathrm{n}$ of

and Is initiated atter

carbon source [ 1]. S

are referred to as mei

rof meiosis-specific

inducer of meiosis) [3

I

1 functions as a repre

repression, the genes

pression) and RGRI a।

rase II mediator subur

irectly or indirectly re

Post jstaddon.

Reply $x$

Reply $X$

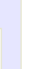


5. Attach File Tool - for inserting large amounts of text or replacement figures.

Inserts an icon linking to the attached file in the Q appropriate place in the text.

How to use it:

- Click on $\&^{\text {- }}$

- Click on the proof to where you'd like the attached file to be linked.

- Select the file to be attached from your computer or network.

- Select the colour and type of icon that will appear in the proof. Click OK.

The attachment appears in the right-hand panel.

:hondrial nreparatior ative da ie extent of membra I, malondialdehyde ( (TBARS) formation.' inad bu biak marfam
6. Add stamp Tool - for approving a proof if no corrections are required.

$\Omega$ Inserts a selected stamp onto an appropriate place in the proof.

How to use it:

- Click on $\Omega$.

- Select the stamp you want to use. (The Approved stamp is usually available directly in the menu that appears. Others are shown under Dynamic, Sign Here, Standard Business).

- Fill in any details and then click on the proof where you'd like the stamp to appear. (Where a proof is to be approved as it is, this would normally be on the first page).

)t the Dusiness cycie, starting with the on perfect competition, constant ret

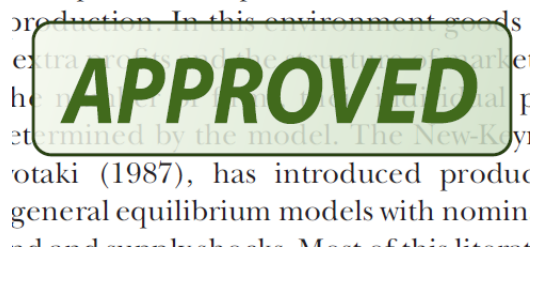

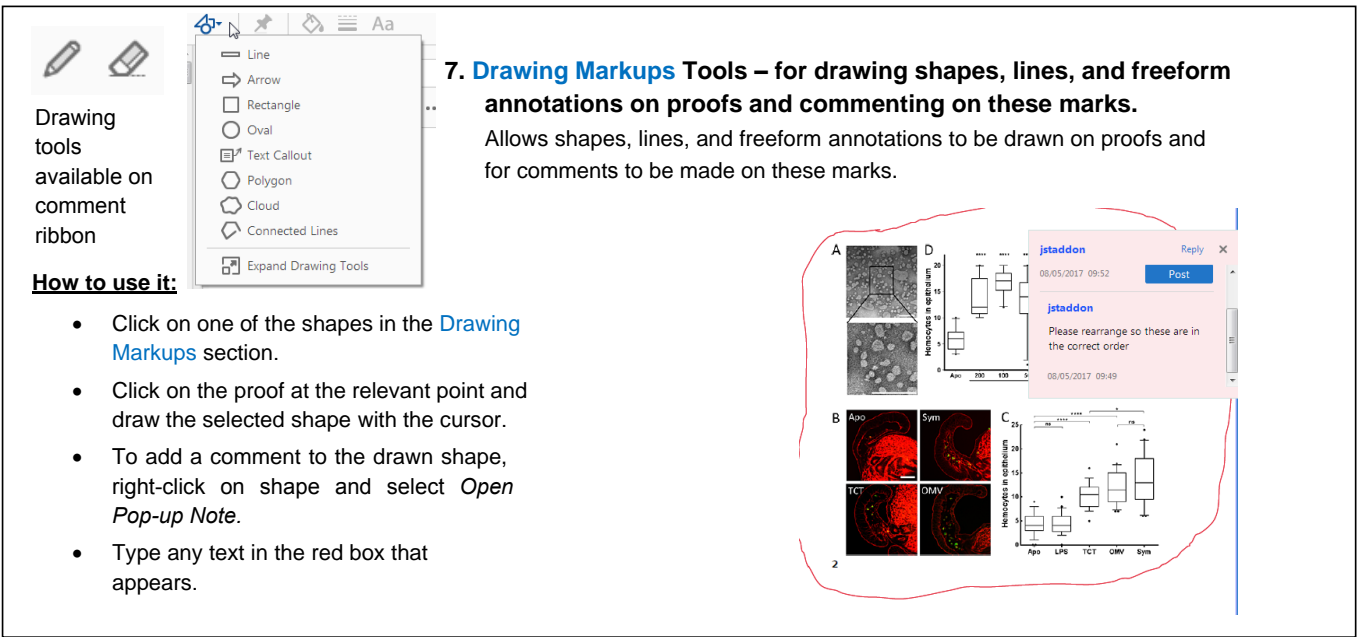

For further information on how to annotate proofs, click on the Help menu to reveal a list of further options:

Welcome...

?) Learn Adobe Acrobat Reader DC..

About Adobe Acrobat Reader DC...

About Adobe Plug-Ins...

Generate System Report...

Repair Installation

Check for Updates... 


\section{Author Query Form}

Journal: ANTI

Article: 12423

Dear Author,

During the copyediting of your manuscript the following queries arose.

Please refer to the query reference callout numbers in the page proofs and respond to each by marking the necessary comments using the PDF annotation tools.

Please remember illegible or unclear comments and corrections may delay publication.

Many thanks for your assistance.

\begin{tabular}{|l|l|l|}
\hline $\begin{array}{l}\text { Query refer- } \\
\text { ence }\end{array}$ & Query & Remarks \\
\hline 1 & $\begin{array}{l}\text { AUTHOR: Please verify that the linked ORCID } \\
\text { identifiers are correct for each author. }\end{array}$ & \\
\hline 2 & $\begin{array}{l}\text { AUTHOR: Please confirm that given names } \\
\text { (blue) and surnames/family names } \\
\text { (vermilion) have been identified correctly. }\end{array}$ & \\
\hline 3 & $\begin{array}{l}\text { AUTHOR: Please check the page number in } \\
\text { the text citation Rosas (2006:106). }\end{array}$ & \\
\hline 4 & $\begin{array}{l}\text { AUTHOR: Please give reference details for } \\
\text { ACML (1977). }\end{array}$ & \\
\hline
\end{tabular}




\section{Funding Info Query Form}

Please confirm that the funding sponsor list below was correctly extracted from your article: that it includes all funders and that the text has been matched to the correct FundRef Registry organization names. If a name was not found in the FundRef registry, it may not be the canonical name form, it may be a program name rather than an organization name, or it may be an organization not yet included in FundRef Registry. If you know of another name form or a parent organization name for a "not found" item on this list below, please share that information.

\begin{tabular}{|l|l|}
\hline FundRef name & FundRef Organization Name \\
\hline $\begin{array}{l}\text { Fundação para a Ciência e a } \\
\text { Tecnologia }\end{array}$ & $\begin{array}{l}\text { Fundação para a Ciência e a Tecnolo- } \\
\text { gia }\end{array}$ \\
\hline
\end{tabular}




\title{
Lisbon's Red Belt: A Cautionary Tale on Politicisation and Depoliticisation of the Urban Realm
}

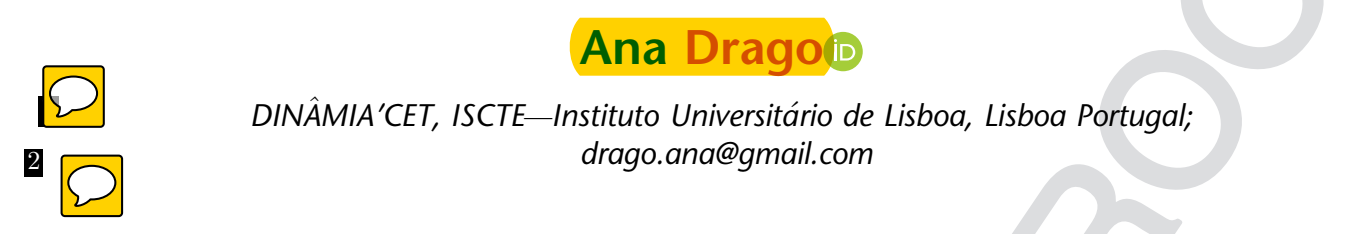

\begin{abstract}
Within the making of Portuguese liberal-representative democracy, the Portuguese Communist Party became a major actor in local government in urban deprived peripheries, shaping Lisbon's Red Belt. In this article, we analyse the communist discourse on the Portuguese urban question, showing how it politicised the urban as a site of unevenness and deprivation, but simultaneously depoliticised it by refusing to acknowledge it as a proper space for conflict. This historical account leads us to a critical debate with proposals that discuss urban politicisation by ontologising "the urban" or "the political" - we argue that these approaches tend to be less helpful in understanding processes of contingent, partial and inter-related forms of politicisation/depoliticisation of the urban in itself. In contrast, we argue for a more attentive theorisation on politicisation-depoliticisation of the urban condition as a most valuable path to grasp situated formulations of citizenship and, hence, configurations of political regimes.

Resumo: No contexto de institucionalização da democracia portuguesa, o Partido Comunista Português tornou-se uma força política central no governo local das periferias urbanas carenciadas - desenhando a Cintura Vermelha de Lisboa. Neste artigo, analisamos o discurso do PCP sobre a questão urbana portuguesa, mostrando como politizou o urbano enquanto espaço de desigualdade e carências, mas simultaneamente o despolitizou, ao recusar conceber o urbano como espaço "próprio" de conflito. Esta análise histórica conduz-nos a um debate crítico com propostas que abordam a politização urbana ontologizando "o urbano " ou "o político" - argumentamos que estas abordagens dificultam a reflexão sobre formas parciais, contingentes e inter-relacionadas de politização/despolitização do urbano em si mesmo. Ao invés, propomos que uma teorização mais atenta aos processos de politização-despolitização da condição urbana oferece um caminho promissor para dar conta da emergência de formulações de cidadania, e dos seus impactos na configuração dos regimes políticos.
\end{abstract}

Keywords: politicisation, urban political, Communist Party, the political, urban ontology, Portugal

Whenever we bring into a dialogue central concepts of critical urban theory such as "the political" and "the urban", we cannot help but remember the threat made in 1968 by young Castells about the impossibility of a "truly" urban theory - the fundamentals of society lie beneath spatial practices, the urban merely mirrors other political structural processes (Castells 1968). For the established and flourishing spatial disciplines this threat always comes as an unnecessary provocation. Urban studies have responded convincingly to Castells (himself providing this response), and it is uncontested that, when convening the political, the "city" 
has been present in its major debates and struggles throughout history. Not as provocation, nor to reinstate an epistemological questioning over the possibility of urban theory, we turn to young Castells as a reminder: the theoretical challenge is to understand if and how the urban is politicised by collective actors, functioning as a category of conflict, and the implications of such a process.

In recent years, the debate over the political has returned to the centre of critical urban theory, with an array of contributions pointing to the politicising dimensions of the "urban experience": the post-political and the politicising city approaches, nurtured by a conversation with post-foundational perspectives (Dikeç 2012; Dikeç and Swyngedouw 2017; Swyngedouw 2009, 2011); re-theorisations on the role of the "city" in framing alterity, citizenship and being political (Isin 2002); and challenges to the entrenched statist ontology in political theory, by focusing on the urban political (Magnusson 2011, 2014).

This paper aims to make a contribution to this debate through an analysis of a situated process where the "urban question" and the political appeared enmeshed-the Portuguese encounter between the societal dynamics of "becoming urban" and "becoming a democracy", in the last quarter of the $20^{\text {th }}$ century.

When, in 1974, a military coup triggered the Portuguese democratic revolution, its urban territories displayed a lack of affordable housing, inadequate transport and urban services that were unable to respond to a population that had been flowing towards "the city" since the 1960s. Within illegal peripheries and innercity slums, the country's housing shortage was estimated in the mid-1970s at 600,000 dwellings, affecting mainly urban areas (Ferreira 1984).

Urban segmentation, deprivation and informality were not unique in Western Europe - during those years, Portuguese immigrants lived in biddonvilles in French suburbs, and Southern Europe displayed what Leontidou (1990) conceptualised as a model of Mediterranean informal urbanisation. However, contrary to Greece and Spain which also went through "becoming" urban and democratic in the 1970s, Portugal's democratic transition was not negotiated among elites - it emerged as a political upheaval, the closest to a revolution in Western Europe in the second half of that brief $20^{\text {th }}$ century that Eric Hobsbawm claimed ended in 1989. This revolutionary transition provided a rupture in a Rancièrian sense-a radical disruption of the institutional apparatus and narratives of legitimation of the authoritarian regime, posed by popular segments (those not accounted for).

The urban erupted from within: housing occupations occurred only days after the coup, and, in shanty towns and the poorest neighbourhoods, an urban movement flourished. Residents' commissions began paving roads, building sanitary systems and opening kindergartens in squatted houses, embodying the democratic claim - a denunciation of popular deprivation, but also as a radical demand of political emancipation to popular classes, whose voices had been excluded from the political realm throughout decades of authoritarian rule (Bandeirinha 2007; Downs et al. 1978; Pinto 2013).

This Portuguese popular movement led an extraordinary moment in which the urban question was fully politicised - the urban provided a spatialised form of political organisation (local residents' commissions), and fuelled the naming of a conflict that pitted "the people" against private speculative interests in urban land 
and construction. Going beyond classical demands of social policies, it stood at the core of a conflict over which model of democracy Portugal should pursue: a popular democracy devised around workers and (urban) popular organisations, or a liberal model of representation, mainly restricted to political parties (Pinto 2013).

However, by 1976, the new democratic Constitution consecrated a pro-liberal model of democratic representation, and municipal government become a monopoly of party representation (Drago 2017). Prevented from gaining access to political institutions, and within a context where the majority of political parties aimed for European integration in order to put to rest the socialist pledges of the revolutionary period, most residents' commissions withered, and the urban movement disappeared (Pinto 2013).

Yet, one has to ask: did the vibrant politicisation of the Portuguese urban question melt away into political apathy? Did the politicising effect of the urban everyday experience of deprivation just vanish?

In this article, we argue that the urban question remained a central feature in the configuration of Portuguese democracy, and we point to Lisbon's Red Beltthe communist municipalities surrounding Portugal's capital-as a central political response of popular urban peripheries to the shortcomings of liberal democratic urban policies.

Since the first local elections, in 1976, the Portuguese Communist Party (PCP) and its allies conquered various municipalities in Lisbon's deprived suburbs. In fact, Lisbon's "Red Belt" has been a constant throughout four decades of the Portuguese democracy - by 2017, more than 25 years after the fall of the Berlin wall, and despite the withering of the French Communist Party and the disappearance of the Italian Communist Party, the Portuguese communists still held government in half of the 18 municipalities of Lisbon's Metropolitan Area.

Traditionally, Western communist parties tend to be analysed as a product of a supposedly transparent class conflict, rooted in economic/production relations. Could it be, as young Castells claimed, that "the urban" has no say in this case, and that communist embeddedness in the deprived urban territories of Portugal should be explained as a political representation of class only because they are workers?

In this article, we argue that during the first decade of Portuguese democracy - a period where the meaning of "democracy" was still under dispute-the communists formulated a discourse on the urban question that provided political representation for the everyday experience of popular urban segments. Inspired by Holston's (2008) proposals, we refer to this discourse as oppositional citizenshipa discourse that politicised the urban as a site of inequality, but depoliticised it as proper space of conflict in favour of class antagonism. Furthermore, we contend that $\mathrm{PCP}^{\prime} \mathrm{s}$ discourse on Portuguese urban territories was a determining element in drawing possibilities and restrictions of the political realm in a post-revolutionary period, and, consequently, in the configuration of Portuguese democracy: rather counter-intuitively, and while contesting liberal order, this oppositional model channelled urban contestation towards party's representation in political institutions, fostering urban popular integration into the new regime. 
But mainly, we believe that Lisbon's Red Belt provides a useful case to discuss how forms of politicization-depoliticisation of the urban are central to providing models of citizenship and forms of organisation, participation and conflict in political regimes. This is relevant because, quite often, contemporary political subjectivities that established conflict over "constituted order" tended to disregard the urban as a space for the articulation of political subjectivities/struggles in favour of universal and/or national scale, downplaying urban conflicts as "particular" or "local" and not centred in the "proper" conflict/scale. We contend that these processes have consequences on practices of participation, disputes over rights, definitions of spaces of conflict, models of resistance and/or integration are consented and/or contested. Therefore, an attentive theorisation on politicization-depoliticisation of the urban is needed in order to account for political configuration of contemporary regimes.

We discuss this theoretical stance by engaging in a critical conversation with recent theoretical proposals that have aimed to articulate the urban and the political, namely proposals of an urban ontology, as put forward both by Isin (2002) and Magnusson (2011, 2014); and Dikeç and Swyngedouw's (2017) reflections towards a political ontology to approach the urban. We claim that although these proposals provide sustained conceptualisations of a politicising urban experience, their ontological stance makes them less attentive to the interrelated dynamics of politicisation-depoliticisation of the urban condition in itself, and the implications of these processes. In contrast, we argue that critical theory has not only to question how (urban) politicisation is possible, but quite fundamentally, what is being politicised. Following Holston's insight on the role of the "struggles of the city" in the formulation of citizenship, we contend that analysing how "the urban" is politicised-depoliticised constitutes a more valuable path in accounting for the political configuration of regimes. In fact, a fundamental contribution that urban studies can provide to critical theory is a conceptualisation that pays more attention to the complex, fragmented and contingent ways through which the urban is politicised-depoliticised in the discourse of political actors, and the implications of such processes in opening or closing possibilities of emancipatory change.

\section{Politicisation through the Urban, Politicisation of the Urban}

The relation between the urban and the political has always been challenging: contrary to other theoretical constructs that guide us through the study of political conflict - such as capitalism, colonialism or patriarchy - "the urban" is not (immediately) constituted upon a relationship of power/conflict, rather it rests on theoretical distinctiveness.

Responding to this challenge, two approaches have emerged offering ambitious theoretical paths: the proposal of an urban ontology to account for the political, and the proposal of a political ontology to understand urban conflicts.

Theorisation of an urban ontology can be traced to the work of both Isin (2002) and Magnusson (2011, 2014). These authors offer a reading of the city/ the urban as the central mechanism in political subjectivation, arguing that urban 
experience fosters group/identity formation in the presence of difference, leading to formulations and struggles over the constitution of political community. Thus, urban ontology proposals place encounter through the urban as an adequate configuration of politicisation, sustaining a symbiotic relationship between the urban and the political (Magnusson 2014). Notably, Isin (2002:50) conceives of the city as a difference machine that enables being political:

The city is neither a background to these struggles against which groups wager, nor is it a foreground for which groups struggle for domination. The city is the battleground through which groups define their identities, stake their claims, wage their battles, and articulate citizenship rights and obligations ... The city as a difference machine relentlessly provokes, differentiates, positions, mobilises, immobilises, oppresses, liberates. Being political arises qua the city and there is no political being outside the machine.

A second theoretical path takes a different route - it starts by presenting an ontological account of the political, and places it in theoretical relation with the urban realm. This approach, notably the work of Dikeç and Swyngedouw, rests heavily on a dialogue with post-foundational authors, chiefly Jacques Ranciére, conceiving of the political as a disruption/interruption of constituted order in the name of equality (Dikeç 2012; Dikeç and Swyngedouw 2017; Swyngedouw 2011). As disruption, the political renders visible contingency and inequality entrenched in the hierarchical allocation of spaces, functions, and roles in a given social order, and in this sense, differs from "ordinary" forms of politics that do not fully address constituted order. Consequently, it allows not only a privileged point of analysis of historical-societal structuring, but also a quest for (moments of) interruption in the structures of domination that bring up transformative possibilities. Maintaining this sharp divide between the political and politics, Dikeç and Swyngedouw (2017:2) proposed a classification of urban movements as social or political-the former being "particular" and centred on "contentious issues that have an impact on urban policy procedures and objectives", while the latter goes beyond, addressing constituted order and everyday practices.

Notably, although these ontological perspectives are different, they both seem to locate politicisation within the urban everyday experience. First, the city provides encounter/co-presence of difference, allowing for political subjectivation/group formation by drawing lines of identity, alliances and antagonism. Second, the urban imposes the experience of governmentality on everyday life-an overlapping array of authorities and modes of regulation of practices/subjectivities, that run across urban everyday life, fostering politicisation towards institutions and techniques of government. Third, the "city" allows acting conflict that operates as a broad politicisation device. And finally, the "city" allows participatory political experimentation through direct engagement in creating new sociabilities/spatial practices. In a nutshell: the urban politicises - and we certainly share this view.

However, when facing the messy empiria of historical processes, can we find guidance within these proposals about "what" is being politicised through this urban experience? Let me put this almost as a tongue-twister: urban politicisation seems to be everywhere, but politicisation of the urban is hard to distinguish. 
This question is important because politicisation processes always pose a double interrogation: how is politicisation possible, and what is being politicised. We contend that the ontological stance in each of these proposals creates difficulties in answering this latter demand, and leads to the neglect of a more attentive theoretical discussion of (the possibility of) the urban becoming in itself the object of politicisation.

We argue two points. First, the cost of carrying ontologies of the urban/the political for urban research is high: when ontologised, "the urban" tends to become a trans-historical concept/process; and, similarly maintaining an ontological interpretation of "the political" within research leads us to neglect partial or tentative forms of (everyday) politicisation of the urban condition. Second, these approaches do not respond to a central question: if the urban is not a theoretical construct based upon a constitutive conflict, how do we conceptualise it to be politicised in itself, becoming a category of conflict appropriated by collective actors, and what are its consequences?

In the way that Isin and Magnusson present it, a proposal for an urban ontology to account for politicisation bares the risk of suggesting a conflation of both concepts - "if the urban is the political", writes Magnusson (2014:1572). "The urban" tends to appear as a reference for all political interaction: a trans-historical concept, devoid of socio-spatial anchorage, allowing an analysis of the Greek polis and present-day "mega-cities" with the same conceptual tools. This might seem appealing-however, we believe that for present-day debates it is misleading. Critical urban theory rests on the hypothesis that the urban condition, as Henri Lefebvre pointed, is qualitatively distinct from analytical categories of pre-industrial "city-ness". Industrial and capitalist structuring through spatial tools/policies have deployed institutions, techniques of government, social identities and political "scales" that are distinctive, and not a just a quantitative leap in human agglomeration. Temptations to depict the urban as an all-encompassing theoretical construct are definitely present in contemporary analyses: as the urban rescales and re-articulates in multiple and uneven processes with other "spaces" of politico-economic structures, views on planetary urbanisation seem to advise a blurring of the urban's "constitutive outside" (Brenner 2014; Brenner and Schmid 2015). However, and following recent debates (see Jazeel 2018; Roy 2016), we believe that theoretical distinctiveness from the "non-urban" is, in fact, what renders "the urban" a useful concept when analysing particular forms of conflict/ political subjectivation in contemporary economic-spatial restructuring.

Regarding what we have addressed as a political ontology approach to urban politicisation, its consequences in urban research have been recently debated concerning the proposals on post-democratic or post-political condition/city, that rests on the same intellectual framework. As Beveridge and Koch argued, this polarisation between the political and "ordinary" politics "is too narrow a basis to capture the contingencies of actually existing urban politics" (2017:32). Accompanying these remarks, we argue that such a focus on conflict over "constituted order" creates a peculiar paradox - it relies on politicisation through the urban everyday experience, but creates a blind-spot around how political subjectivities ordinarily politicise the urban, creating possibilities for urban change even if they 
do not confront the "whole" social order. Most notably, the political ontology approach is not clear about what is being politicised. Consider present-day antineoliberal "urban" protests: one can accept urban politicisation at work in these movements, and also as entailing a place politics as contended by Mayer et al. (2016). However, as these movements tend to identify their antagonists beyond the urban, one has to ask if conceiving them as urban political movements is a theoretical strategy that does justice to the "scale" and the arena of conflict defined by these movements. In a sense, in the political ontology proposal, the urban appears as subsumed or equivalent to uneven constituted (liberal-capitalist) order, and it seems to be presumed that anti-systemic conflict politicises the urban question. However, as we try to demonstrate in this article, antagonism towards liberal order does not necessarily imply a full politicisation of the urban realm, and this has the most relevant consequences.

In his work over Brazilian urban peripheries, Holston proposes that "contrary to so much $19^{\text {th }}$ and $20^{\text {th }}$ century social theory about the working classes, members of these classes became new citizens not primarily through the struggles of labour but through those of the city" (2008:4). These struggles of the city point specifically to politicisation of the "urban condition". Holston shows that, within the context of uneven urbanisation, "traditional" urban politics (housing, urban services, etc.) foster popular engagement with questions of equality, membership of the political community and the claim of rights - organising formulations of citizenship. Here, citizenship is not seen as a set of rules that presents itself as universal, but as a situated relationship between state and society, aggregating both the formal attributes of membership to political community and the political imagination that produces/disrupts them.

Departing from this insight, we argue that a more attentive theoretical focus has to be placed upon the forms and consequences of politicisation of the urban condition. Certainly, ontologies of the political, namely the work of Jacques Rancière, have provided a fresh philosophic perspective on antagonistic moments/ conflicts that both challenge and unravel uneven social order/normalised social relations, distinguishing them from political practices of techno-capitalist management. However, we suggest that critical social theory must engage in a more ethnographic approach: searching for claims/actions driven by judgements of illegitimate societal inequality/power embedded socio-political practices - that is, politicisation of spaces/relations, even if they proceed in a partial and fragmented form. This implies, for our discussion, a step back from an ontological grounding to tackle the relation among the urban and the political; and a step forward towards an analysis of situated processes where the urban becomes a political category.

First, we must assume a sharp differentiation between the urban as a category of analysis and the urban as a category of conflict. The former functions as a theoretical construct that allows us to grasp how politicisation processes can occur. However, politicisation, even when embedded in the urban experience or acted in "the city", does not imply that the urban condition is itself politicised. To the contrary, the urban as a category of conflict refers to processes in which 
urbanisation processes/the urban condition is explicitly claimed/named as an arena of conflict by collective actors - creating the "we" of conflict.

Second, politicisation processes are not binary switches. Most often we are in the presence of inter-related strategies of politicisation/depoliticisation led by political actors (see Darling 2014). And because depoliticisation "is about redrawing boundaries, limiting the scope of contestation and restricting the ways people make sense of themselves as political agents" (Beveridge and Koch 2017:40) critical accounts of political formulations that draw boundaries on where, who and what is "proper" conflict enable us to understand the contingent, partial, and often overlapped of forms of conflict and consent towards different spaces/societal relations within political formations.

Third, in politicisation processes there is no self-sufficiency in the explanatory value of "the urban". Even when the urban becomes a category of conflict for collective actors, it is crossed by multiple subject positions deriving from other socio-spatial processes/relations - what Jazeel argues that we can see as supplements "that have their own generative dynamics that cannot be collapsed into the capacious logic of urbanization" (2018:411). This is not a flaw, nor an exclusive characteristic - maybe, as an epistemological strategy, we can suggest that the formation of major political categories/subjectivities is always crossed by the logic of "supplements". But significantly, the urban condition allows the articulation of multiple subject positions as citizens' movements (Castells 1983), directing them towards conflict over the constitution of the political community.

Finally, an analysis of the ways in which the urban is politicised-depoliticised provides a most valuable tool to account for configurations of political formations. It points us to the diverse, concurrent and conflictual formulations of citizenship that co-exist in a given social formation, as they pose recurrently the question of territorialised-direct political participation towards abstract models/spaces of political participation. In other words, it allows us to grasp situated processes of institutionalisation/conflict over categories of membership, rights and models of political participation in a given political community.

With this in mind, and within a context of the making of a western European democracy in the late $20^{\text {th }}$ century, we aim to provide a reading of the formulations of citizenship that arise from the communist discourse over this experience of Portuguese urban popular segments: becoming "urban" and "democratic citizens".

\section{Readings on the Southern European "Red Cities"}

In the aftermath of "the fall" of 1989, historiography begun to revisit the $20^{\text {th }}$ "century of communisms". Two approaches emerged: one dedicated to a postcommunist debate; and the other revisiting the communism movement from a more socio-cultural perspective.

The first approach has focused mainly on ex-USSR states. For the purpose of this article these approaches are not entirely useful: our discussion is not a quest for the communist city/urban, rather an interpretation of the role of communist discourse/representation of the urban deprived segment in the configuration of a 
"western" democracy. While Western communist parties were a striking actor of conflict and resistance to liberal democracies, East of "the wall", communists were in power. Even if Western European communist parties are not a mere aggiornamento of national traditions of radical popular protest, their position within constituted liberal order is central to our argument.

A second historiographic approach has revisited the international communist movement opening promising perspectives for the study of communist popular culture, namely the array of organisations that allowed it to function almost as a counter-society in some countries in Southern Europe. This approach has also focused on French and Italian "red cities". We can find partisan accounts of "red" urban policies in Italy in its prime (Jaggi et al. 1977) or post-1989 (Anderlini 1990); some political science approaches to French communist local governments (Schain 1985); comparisons of communist local party structures between France and Italy (Blackmer and Tarrow 1977) and, more recently, a number of researchers discussed les territories du communisme in France (Bellanger and Mishi 2013). However, most of these approaches tend to use communist urban governance to explore the structuring of communist parties - its exceptionality both in party form and social embedding in Southern Europe - and not so much as an inquiry into their discourse on the urban question.

There are however two authors who widened the discussion about the role of "the urban question" to communist embeddedness in Western Europe. Fourcaut (1986) provided a remarkable account of inter-war communist rooting in a deprived Parisian suburb, analysing both the impact of the ideological battles that crossed the international communist movement in local government, and communist discourses in French political debates concerning deprived and peripheral urban workers - les classes dangereuses. Later, Stovall (1990) returned to the same municipality, showing how communist urban governance had embedded itself prompted by socio-demographic changes in the Paris region, along with the production of a discourse and policies directed to the mal-lotis - the residents of defective allotments - providing an innovative account of how the status of urban dweller came to be so central in working class politicisation, forging long-lasting bonds with communist subjectivity. We aim to take this analysis one step further, placing communist embeddedness/discourse on deprived urban popular classes into a conversation with the configuration of a socio-political formation.

\section{The "Urban Question" and the Portuguese Communist Party in the Democratic Transition}

The Portuguese metropolisation process can be traced to the mild modernisation policies launched in the mid-1950s, and which continued during the 1960s. During these years, an industrialisation boom developed around Lisbon and Oporto, leading to a mass exodus towards the outskirts of these two cities (Salgueiro 2001).

Enmeshed in a colonial war and historically linked to private land interests, the authoritarian regime was unable and unwilling to provide housing policies and urban services to cater for the migration of people to the "city", and in the 
mid-1970s, Portuguese urban territories portrayed a fragmented and unequal metropolitan map that had expanded through deprivation and "illegality" (Ferreira 1984; Salgueiro 2001; Soares et al. 1985).

In 1974 a military putsch put an end to the authoritarian regime, and Portuguese society was promised a democratic and socialist future. However, as the political turbulence rapidly showed, there were different interpretations of what democracy and socialism meant (Pinto 2013). As the political struggle unfolded, a revolutionary atmosphere spread through the country: large farms were seized by rural workers; in some factories workers envisaged self-management; and the energy sector, transport companies and banking system were nationalised.

The encounter of the urban with the democratic claim after the coup was both hopeful and tumultuous. A myriad of popular organisations flourished, mainly in the poor neighbourhoods, occupying empty houses, abolishing rents in shanty towns, building roads and basic infrastructures. These struggles voiced a politicisation of the urban - a straightforward discourse that portrayed it as a site of conflict between the "people" and speculative private interests.

The relevance of this urban popular movement should not be underestimated:

the series of urban movements involved large numbers of people from different classes and social groups, and organised them around concrete problems. This was the basis of a creation of an ill-defined but clearly extant popular movement ... Eventually necessity began to be converted into a virtue. The urban movements came to see themselves collectively as part of an alternative to the traditional state. (Downs 1983:174-175)

These urban popular organisations stood at the centre of the struggle for a grassroots popular democracy that would incorporate them into local democratic institutions (Pinto 2013). But during the constitution-making debates of 1975-1976, their expectations of a participatory city were exchanged for the promise of a social rights city: the regime reserved institutional spaces for political parties, while consecrating housing rights as part of democratic citizenship (Drago 2017).

However, on account of the international economic crisis of the 1970s, along with a "legislative counter-revolution, that progressively voided or revoked a good mount of the most advanced objectives and accomplishments of the revolutionry process" (Rosas 2006:106), public policies gave no adequate solution to the urban housing shortage within the first decade of democracy (Ferreira 1987).

What was the response of the urban and deprived working segments? First, there was a cultural-economic response through an overwhelming movement of self-promoted housing construction, where the "illegal" sector held significant sway (Castela 2011; Soares et al. 1985). In 1985, a decade after the revolution, some scholars estimated that $80 \%$ of new houses were individual/families' initiatives, and about a quarter of those were "illegal" (Ferreira 1987:40-41). Second, we argue there was a political answer - a vote for the communists in municipal government in the deprived peripheries of the Lisbon Metropolitan Area (LMA).

While gathering electoral support in the rural south and in Lisbon's industrial peripheries, PCP remained excluded from national government arrangements: "the bigger [PCP's] political success, the less likely it will be its approximation to 
the sites of political power ... all the other parties refer themselves to the communist's actions, but always to fight and deny them" (Aguiar 1983:294). As so, PCP can be interpreted as a political subject "other" in the production of the liberal model of the Portuguese democratic regime, in a double sense. First, the central conflict of Portuguese democracy after the revolutionary period was constructed around the Cold War divide, placing the communists in opposition to a "European-style" democratic Portugal. And second, the communists gave political representation to popular segments that were experiencing the shortcomings of the democratic promise.

Nevertheless, by producing an anti-liberal discourse about what democracy "means" mainly centred on public control and a re-distributive claim, and by providing oppositional (but not insurgent) institutional representation, the PCP, counter-intuitively, can be seen as a decisive agent of popular integration into the new regime.

\section{A Communist Discourse for the Portuguese Urban Question}

The years between 1976 and 1985 constituted a period of consolidation for the new regime, arranging state machinery for the democratic paradigm. But it was also a decade of political "adjustments", away from the project of a socialist society pledged by the Constitution of 1976 and towards a European social liberal model, aiming for an integration in CEE that occurred latter in 1986. During those years, PCP achieved remarkable electoral results in Lisbon's peripheries. In 1979, and again in 1982, the Portuguese Communist alliances governed 12 of the 18 municipalities of Lisbon Metropolitan Area. Comparing party politics in local governance, Silva concluded for a communist distinctiveness in relevant areas: the communists spent more and mainly on social services; reached more for funding schemes for social housing provided by Central State; they made major investments in basic sanitation during the initial terms of office; had an early involvement with formal instruments of territorial and urban planning; and directed more investment to create collective facilities, namely cultural and sportive amenities (Silva 1995).

However, it is difficult to discern a "communist city" in Lisbon's peripheries. First, the Portuguese state remained highly centralised: housing was a central state policy, and because of Lisbon's metropolitan planning, some municipal planning and even private construction initiatives were ratified at a regional or central level, rendering it difficult to assess urbanistic differences in communist territories. Second, local finances rested heavily on building permits ... and people needed houses - the story of urban pressure is evident throughout Lisbon's peripheries. Finally, deprivation in basic urban services and infrastructures was so striking that different parties in Lisbon's peripheries initially attempted to answer it in a similar manner.

Therefore, we would like to focus on the political interpretation of the urban realm put forward by the Portuguese communists during the first decade of the democratic regime. 


\section{The Urban as a Site of Deprivation}

I am a councilman in [a county next to Lisbon] and I know the problems of my hometown. It's the case of the sewage system, that is saturated ... It's the 30 or more slums, with no sewage, no running water, and where the fountain remains, as one hundred years ago, the only water source for tens of thousands of people, who walk long routes everyday with jars on their backs ... the existing waste dump, in open air and with the height of a six-storey building, for being overloaded can no longer be kept in use. It's the housing problem in this municipality, a typical case of real-estate speculation that flourished during fascism and that is rising again. It's three hundred thousand people living in deprived neighborhoods, it's tens of thousands of families, of four, five or six people living in rooms, it is forty thousand people living in Brandoa's illegal neighborhood. (DAR 1977:3419)

In the Portuguese communist discourse of those years, the urban realm is portrayed essentially as a site of deprivation: the lack of adequate housing provision, transport and urban services draws an image of a multiplicity of social problems, and Lisbon's peripheries tend to be described as "dormitory towns" and "cement forests". As a communist architect argues, the city appears as a place of "anguished quotidian":

the "present-reality" that the city offers to its inhabitants is felt every day in a real manner by large sections of the population - a quotidian paced by long waits, uncomfortable and slow public transportation; weariness; sparse, expensive and overcrowded housing; dirtiness; distant and outdated schools and hospitals. (Dias 1977:8)

This image of urban territories as spaces of deprivation is read as a legacy of the former regime: "fascism was not only the eradication of liberties ... the situation of misery and marginalisation in which a large part of the people lived, and still live ... its inseparable from fascist domination" (Costa 1981:38). The answer certainly arises from the communist political project: "how to find a way out for the urban problem? ... It's obvious that the country's transformation into a socialist society is the necessary and sufficient condition to solve the problem" (Almeida 1977:39). However, towards the end of the 1970s, a Portuguese socialist transition was not on the horizon. Instead, for the communists, the "urban problem" was to be addressed through a number of sectoral policies, provided by Central State and local government, as consecrated in the democratic Constitution-redistributive policies, namely public housing policies, and public control over urbanisation that would allow for the effective implementation of the democracy's social rights agenda. But curiously, in the communist magazine direct to local councilmen, there is no appeal for images of what a socialist city could be, no resonance of modernist socialist models, and almost no reference to urban social policies from other Western Communist parties or the USSR.

In some ways, the urban sustains the role of PCP as an "insufficiency revealer", pointing unfulfilled promises of the democratic regime (Aguiar 1983:300). While the urban showed inequality perpetuated by pro-liberal government policies within the democratic regime, for Portuguese communists there seems to be no praise for the "city", and no discernible political potential in the urban 
realm-PCP does not seem to believe in the transformative potential of an urban political movement. A formulaic speech appeals to "workers class and popular movement" (PCP 1979) — pointing bluntly to the primacy of economy-based political categories that do not necessarily correspond to deprived urban segments.

The appeal for a socialist city points to a strategy of applying a set of policies at the state level that could unleash a change in urban land ownership structure, and public control over its uses. However, the actor that could foster socialist urban policies does not arise from a conflict within the "city" — the political potential of working class struggles arises from productions relations, not urban politicisation. Thus, the Portuguese communists politicise the urban as a site of unevenness, to be addressed through public control of urbanisation and economic redistribution, but simultaneously depoliticise it by not conceiving of it a space for the political to arise, or for the articulation of a transformative political subjectivity.

\section{Politicising the Urban: Urban Land, Housing, and Class}

One year after the democratic coup, the PCP presented a rather unclear proposal of urban reform in their project for the new Constitution: "The State will define and carry out an urban reform, covering a policy of construction, urbanization, housing, public transport and environmental protection, planning the use of urban land" (DAC 1975:681). There was no mention of urban land nationalisation, that would appear later during the Constitutional debates, and was included in its final text in a way that implies that expropriation would be the exception, rather than the rule, of public policy towards urban territories (see Drago 2017).

Although State-led expropriation of urban land increased in the first years of the democratic regime, this issue would become paramount in Portuguese communist discourse about the urban question. Public control over urban land was presented by the PCP and its allies through different solutions: either nationalisation, municipalisation, or the right of preference by public authorities, in order to allow planning and public housing policies: "In the metropolitan areas of Lisbon and Oporto, the gravity and complexity of existing problems and the magnitude reached by speculative activity over land and construction advises taking vigorous action ... moving progressively to land nationalization" (Carvalho 1978:36).

Communists argue that urban land nationalisation/municipalisation is the only way to control market forces, and provide housing solutions in the metropolitan areas: "[for the] planning of predominantly urban areas ... enable municipal bodies to control the use of land, so to make possible orientation and constrain private initiatives" (Costa 1978:38). Similarly, as a response to the housing shortage "there is a need to construct a lot to override the existing shortages ... the population's low level of income requires launching vast operations of social or rent controlled housing, which implies a policy of nationalization or municipalization of urban land" (Sá 1977:34). And, although the PCP tends to assign housing policies as a national, central state responsibility, authors in its publications admit assigning social housing to municipalities if they are given control over urban land and proper funding (Gomes 1982:55-56). 
However, the issue of urban land ownership was not an easy one. The overwhelming "individual" housing promotion that took place during these years, along with a significant increase in "illegal" housing construction, particularly in the poor urban municipalities where the communists were in office, created a difficult problem to solve. The "class reading" of the illegal housing social process was not straightforward:

It is necessary to take into account in every decision that different classes and segments intervene in this phenomena [of illegal construction], from workers' families that struggle for the right to a roof, to speculative plot sellers ... ranging through small, medium and high bourgeoisie segments ... it is necessary, from the standpoint of a clear class politics, a process that takes into account not only the legitimacy of the present interests, but also if those interests are harmful to fundamental collective values. (Costa 1981:37)

Throughout these years, communist councilmen had to make difficult decisions about "illegal" housing: allowing illegal neighbourhoods to access the electricity grid; suspending tenant payments of expropriated illegal dwellings but deciding that the municipality would continue to pay those rents to poor landlords, while compensations were not decided in court; negotiate or expel illegal occupants of public housing initiatives; and decide if they were to tear down recently built illegal family houses. A ferocious opponent to illegal land plotting, elected in a communist coalition, tells of his experience with the municipal team that handled illegal construction:

there was a construction being built, with signs of being inhabited ... Inside, there was some old stuff, some beds, etc. ... We, men who wished that in our county things would not worsen, were sensitive to human problems. There was nobody there, we didn't know if all that was just a cover, or if it was really someone's shelter. In these circumstances, we hesitated. We only tore down the stairs that led to the first floor. (ACML 1983:57)

The communist municipalities mainly envisaged operations of urban regeneration of illegal housing areas, negotiating with dwellers that ostentatiously tended to present themselves as owners' associations, and not residents' commissions as during the revolutionary period. These processes took decades to solve.

Above all, the PCP points to urban land as the core of urban conflict: those who control it, control the urbanisation process. Only by controlling the urbanisation process can public policies provide economic redistribution and effectiveness of social rights. The urban is, thus, politicised as a site of antagonist interests: the need of the people for housing provision versus private and speculative interests.

\section{Depoliticising the Urban as a Space for the Political: Proper Institutions to Solve "Concrete" Problems}

The most significant sign of communist disregard for the political potential of the urban realm was made evident by its absence in Álvaro Cunhal's book, published in 1985. In this year, PCP had an electoral setback, integration in EEC was about 
to be officially signed, and Gorbatchev's Perestroika was emerging. However, the PCP's historical leader makes no reference to the urban movements and its socialist claim that agitated Portugal in the aftermath of the coup of 1974, nor to Communist local urban government experience and achievements. There is only one reference to territorialised spaces of the political:

International experience shows numerous cases in which the decisions of replacing company cells for neighborhood cells, workplace cells for place of residence cells, assigning sometimes to unitary social or political organisations the political direction of the company's activities, matched an ideological fading and an abandonment of class objectives in those parties. (Cunhal 2002:61)

This rejection of territorial/neighbourhood organisations as the main root of party organisation goes hand in hand with the $\mathrm{PCP}^{\prime} \mathrm{s}$ discomfort with the political ambitions displayed by popular organisations during the revolutionary atmosphere of 1974-1975:

after April 25th of 1974 and almost all over the country, thousands of mighty unitary organizations arose, turning to solve a number of concrete problems ... roads and streets were built, houses were raised, standpipes were built, kindergarten, playgrounds and social centers were opened ... however, during the revolutionary process, opportunistic conceptions distorted the meaning and objectives of these activities ... presenting territorial based popular organizations as an authentic "popular power", aiming to prevent any cooperation with local government, diverting Resident's Councils from the struggle to solve the people's immediate and concrete problems, contributed to sowing delusion which led, in some cases, to its demobilization and frustration. (Medina 1977:10)

PCP's suspicion of political action arriving from urban popular organisations is no surprise for a Leninist party. Castells explains it:

by definition, the concept of social movement as an agent of social transformation is strictly unthinkable in the Marxist theory. There are social struggles and mass organizations, but there cannot be conscious collective actors able to liberate themselves ... movements had to accept-so the argument went-that they could not produce history on their own. (1983:299).

Other factors contributed to this view. First, the leading generation of the Portuguese Communists in the mid-1970s had gained its rule against the anarco-syndicalist tradition of Portuguese labour movement in the first half of the $20^{\text {th }}$ century: the idea of a radical popular movement as a revolutionary subject was defeated by a conceptualisation of vanguard class party organisation (Neves 2008). Second, the urban popular movement in 1974-1976 was heavily participated in, and at moments, hegemonised by far-left parties with a conflictive relation with the PCP (Pinto 2013). And third, in the institutional arena, PCP was always attacked by pro-western parties as being "non-democratic". Consequently, a vigorous defence of the institutional forms of the democratic regime was always a valuable strategy of legitimisation for a party that faced the risk of being banned during the confrontations that marked the end of the revolutionary period. In this sense, in the communist "literature", neighbourhood organisations were praised 
for their voluntarism, but were always reminded that they existed to solve "concrete problems", and were dependent on legitimate local government.

This is quite clear in the ambiguous relationship of the PCP with the Serviço de Apoio Ambulatório Local (SAAL), a policy launched in the revolutionary period that aimed to provide technical support to housing solutions for extremely deprived neighbourhoods, involving them in the solutions envisaged (see Bandeirinha 2007). Several operations were launched, but by 1976, Government transferred the process to the newly elected municipalities, and began to delay land expropriation and financial aid. Most projects would never be concluded. From 1977 onwards, SAAL and its technical teams, mostly made up of young, radical and left-wing architects, engineers and social workers, began to be attacked by the "liberal" parties. The major defence of the SAAL came from the far-left parties. PCP never attacked the SAAL, but, it can be said, it did not race to defend it either. In Loures, a county next to Lisbon where the PCP held office from 1979 onwards, and most of the SAAL operations were not concluded, a communist councilman argues:

The SAAL, envisaged to support the organization and initiative of shantytowns in their struggle for minimum adequate housing, was never viewed by us as a solution for the severe housing and urbanism problems that affected the country and quite harshly our municipality ... which, although caused by the same policy, have to be solved by other processes ... we do not excuse ourselves in acknowledging that the SAAL operations contain some errors, and we have even stated that we had some disagreements with the structures that launched them by the fact that many of its aspects pass aside the municipal institutions. But it goes a long way from this to accepting the opposition that has been launched against them. (ACML 1977:7 8)

PCP's position is clear: the "place" for drawing a response to the-urban-as-site-ofdeprivation lies not in self-organising popular initiatives that gather their legitimacy directly from the "people", but rather through the political representation of the workers' alliance with popular segments-the party-in the regime's institutions.

\section{What Urban Democracy Means: Participation Through Institutions to Solve People's Needs}

For Portuguese communists urban democracy tends to have its core in local political institutions, and urban popular participation is channelled to them. In fact, for the PCP, local government was key to securing democratic achievements and preventing counterrevolutionary temptations.

First, it provided legitimisation to the democratic regime by "solving people's problems": "each standpipe, each school, road or track repaired, every nursery, kindergarten or playground ... will be another element that proves through acts the superiority of the democratic regime" (Sá 1978:3). Second, local institutions allowed democratisation of the state apparatus, inherited from the former regime, and rather untouched by the revolutionary process: "it is at the municipal and parish level that the people's control over the processes of solving their problems 
is more effective, leading them to intervene and act towards administrative apparatus" (Oliveira 1978:19). Third, local government institutions were seen as the space for an alliance between working class interests and popular expectationsthat is, a class politics, provided by the working class party (PCP) and supported by the "energy" of popular segments, namely neighbourhood and popular organisations. And finally, participation within institutions fostered class politicisation:

Local governance tends to correspond, increasingly, with a gigantic civic-political school ... men and women, in a slow process ... come to understand, to assume and to exercise democratic power to decide over relevant aspects of their lives ... a progressive conscience that to decide well it is necessary to know and to be with the people. And, being with the people has necessarily an anti-big capital class content, that lives from the people's exploitation. (Costa 1981:37)

\section{Conclusions}

In the aftermath of the revolutionary period and the defeat of a popular model of democracy for which so many urban popular organisations had fought, the PCP became the most relevant political representation in urban popular and deprived peripheries. In this role, PCP articulated a discourse centred on the contradiction between the promise of emancipation of the democratic transition and its shortcomings in the Portuguese urban territories. It did so by politicising the urban as a site of deprivation, unevenness and the prevailing reign of speculative interests; and depoliticising it, by refusing the urban as political space for constituting a political subject other than class. And, because in their reading the working class is indisputably represented by the party, political participation in the urban realm was channelled to places where the working class party was represented and acting: local political institutions.

With this double stance, the Portuguese communists formulated a discourse about citizenship in a democratic regime-providing political institutional representation to deprived urban sectors, and a political claim centred on public control mechanisms over urbanisation, as engraved in 1976's Constitution (that is, a socio-economic socialist strategy to be delivered by a liberal-democratic political system). However, this model implied limiting possibilities for more frequent and feisty urban political struggles. In this sense, PCP's discourse on the urban realm provided an oppositional model of citizenship - an institutionalised contestation of pro-liberal policies, but with little room for political movements. As a consequence, PCP had an active part in "normalizing" political participation within the framework of liberal democracy.

We believe this cautionary tale allows for some theoretical conclusions that go well beyond an analysis of Southern European communist urban embeddedness. First, it signals that conflict towards constituted liberal order does not suffice to create transformative possibilities in the urban political realm. In fact, quite often, movements that established their conflict on universal stance or national scale conceived "the urban" as a particular/local space that either blurred antagonistic political categories, or diverted political movements from their "proper" conflict. That depoliticisation of the urban as space for political subjectification/struggle 
tended to limit the transformative potential of forms of organisation/struggle of urban deprived popular segments. Consequently, we argue that an attentive analysis of those situated enunciations of politicisation/depoliticisation of the urban appears to be a valuable path to account for configurations of forms of participation, consent, resistance, conflict and integration in contemporary political regimes.

Second, as categories of conflict and analysis, class, the urban, and citizenship have articulated and clashed with each other throughout contemporary history, and within critical theory debates. As analytical constructs, they are always present in contemporary debates. But this implies that the central questions are whether and how they were summoned by political subjectivities. In fact, maybe the most relevant analyses are those that provide an interpretation on how our (necessarily) plural categories of analysis emerge as categories of conflict-that is, how class, urban and citizenship articulate, or struggle to impose on each other, when they are reclaimed by political subjectivities. Does the "city"/the urban, explicitly named as such by collective actors, have consequences on political formulations of conflict? If so, we would then be in the presence of an urban political movement, either contesting partial and "thematic" urban policies, or confronting capitalist urbanisation processes as a whole.

In this sense, the question is not only how conflict and political subjectivation arises within the urban realm - it is also about what is said about the urban realm. The usefulness of a more attentive analysis of societal processes of politicisation/ depoliticisation of the urban is not merely a theoretical clarification-it is the recognition that the urban can function as a central, although not unique, concept for grasping both present-day socio-economic restructuring, as well as the production of conflict. If the future is (also) urban, then a strategic path of critical urban theory is to focus on the discourses that politicise/depoliticise such an urban future- discourses produced both by structures of domination, and by the multiple emancipatory movements that confront them.

\section{Acknowledgements}

Research for this article was conducted with the support of Fundação para a Ciência e a Tecnologia, Portugal (Bolsa SFRH/BD/84517/2012). I thank José Neves and Tiago Castela for their comments on some of the ideas that found their way into this article during our Seminar on Communism and the City, in FCSH-UNL, in Lisbon, May 2017. I am also very grateful to Antipode's editor Tariq Jazeel and to the anonymous reviewers for their insights and comments. The usual disclaimer applies.

\section{References}

ACML (1983) "Actas Câmara Municipal de Loures, Livro-108."

Aguiar J (1983) A Ilusão do poder: Análise do Sistema Partidário Português 1976-1982. Lisboa: Publicações Dom Quixote

Almeida L (1977) Para a Definição de uma Política de Solos: Algumas Linhas de Actuação. Poder Local-Revista de Administração Democrática 4:37-40

Anderlini F (1990) Terra Rossa: Comunismo Ideale, Socialdemocrazia Reale, II PCl in EmiliaRomagna. Bologna: Instituto Gramsci Emilia-Romagna 
Bandeirinha J A (2007) O Processo SAAL e a Arquitectura no 25 de Abril de 1974. Coimbra: Imprensa da Universidade de Coimbra

Bellanger E and Mishi J (eds) (2013) Les Territoires du Communisme: Élus locaux, politiques publiques et sociabilités militantes. Paris: Armand Colin

Beveridge R and Koch P (2017) The post-political trap? Reflections on politics, agency, and the city. Urban Studies 54(1):31-43

Blackmer D and Tarrow S (eds) (1977) Communism in Italy and France. Princeton: Princeton University Press

Brenner N (2014) Urban theory without an outside. In N Brenner (ed) Implosions/Explosions: Towards a Study of Planetary Urbanization (pp 1-14). Berlin: Jovis

Brenner N and Schmid C (2015) Towards a new epistemology of the urban? City 19(2/ 3):151-182

Carvalho J (1978) O Direito de Preferência numa Estratégia de Controlo do Processo Urbanístico. Poder Local-Revista de Administração Democrática 8:34-37

Castela T (2011) "A Liberal Space: A History of the Illegalized Working-Class Extensions of Lisbon". Unpublished PhD thesis, University of California Berkeley

Castells M (1968) Y a-t-il une sociologie urbaine? Sociologie du Travail 1:72-90

Castells M (1983) The City and the Grassroots: A Cross-Cultural Theory of Urban Social Movements. London: Edward Arnold

Costa C (1978) Manual de Gestão Democrática das Autarquias. Lisboa: Editorial Caminho

Costa C (1981) Poder Local no Portugal de Abril. Lisboa: Edições Avante

Cunhal A (2002 [1985]) Partido com Paredes de Vidro. Lisboa: Edições Avante

DAC (1975) "Diário da Assembleia Constituinte." http://debates.parlamento.pt/r3/dac/me nu5_dac.aspx (last accessed 11 June 2018)

DAR (1977) "Diário da Assembleia da República." 102:3419

Darling J (2014) Asylum and the post-political: Domopolitics, depoliticisation, and acts of citizenship. Antipode 46(1):72-91

Dias F S (1977) Plano Director de Lisboa: que Lugar para o Povo? Poder Local-Revista de Administração Democrática 3:8-10

Dikeç M (2012) Space as a mode of political thinking. Geoforum 43(4):669-676

Dikeç $M$ and Swyngedouw E (2017) Theorizing the politicizing city. International Journal of Urban and Regional Research 41(1):1-18

Downs C (1983) Residents' commissions and urban struggles in revolutionary Portugal. In L S Graham and D L Wheeler (eds) In Search of Modern Portugal: The Revolution and its Consequences (pp 151-179). Madison: University of Wisconsin Press

Downs C, Silva F, Gonçalves H and Seabra I (1978) Os Moradores à Conquista da Cidade. Lisboa: Sociedade Editora o Armazém das Letras

Drago A (2017) Is this what the democratic city looks like? Local democracy, housing rights, and homeownership in the Portuguese context. International Journal of Urban and Regional Research 41(3):426-442

Ferreira A F (1984) Crise do Alojamento e Construção Clandestina em Portugal. Sociedade e Território 1:29-37

Ferreira A F (1987) Por uma Nova Política de Habitação. Porto: Edições Afrontamento

Fourcaut A (1986) Bobigny, Banlieue Rouge. Paris: Presses de la Fondations Nationale des Sciences Politiques

Gomes A (1982) As Competências das Autarquias Locais no Domínio da Habitação. Poder Local-Revista de Administração Democrática 30:55-57

Holston J (2008) Insurgent Citizenship: Disjunctions of Democracy and Modernity in Brazil. Princeton: Princeton University Press

Isin E F (2002) Being Political: Genealogies of Citizenship. Minneapolis: University of Minnesota Press

Jaggi M, Muller R and Schimd S (1977) Red Bologna. London: Writers and Readers Publishing Cooperative

Jazeel T (2018) Urban theory with an outside. Environment and Planning D: Society and Space 36(3):405-419 
Leontidou L (1990) The Mediterranean City in Transition: Social Change and Urban Development. Cambridge: Cambridge University Press

Magnusson W (2011) Politics of Urbanism: Seeing Like a City. New York: Routledge

Magnusson W (2014) The symbiosis of the urban and the political. International Journal of Urban and Regional Research 38(5):1561-1575

Mayer M, Thörn C and Thörn H (2016) Urban Uprisings: Challenging Neoliberal Urbanism in Europe. London: Palgrave Macmillan

Medina H (1977) O Movimento dos Moradores e a Administração Local. Poder LocalRevista de Administração Democrática 4:7-10

Neves J (2008) Comunismo e nacionalismo em Portugal. Política, Cultura e História no século $X X$. Lisboa: Tinta da China

Oliveira V (1978) Obras Municipais. Atribuições e Competências do Poder Local. Poder Local-Revista de Administração Democrática 5:18-24

PCP (1979) "Teses para o IX Congresso do PCP." Partido Comunista Português. https://ephe merajpp.com/2015/12/05/pcp-ix-congresso-barreiro-31-de-maio-3-de-junho-de-1979/\#jp -carousel-196645 (last accessed 18 July 2018)

Pinto P R (2013) Lisbon Rising. Urban Social Movements in the Portuguese Revolution, 197475. Manchester: Manchester University Press

Rosas F (2006) Pensamiento politico y accion política en el Portugal del siglo XX (18901976): Ensayo interpretativo. In B G Fortes and D P Cerezales (eds) Una História Política de Portugal. La Difícil Conquista de la Democracia (pp 51-64). Madrid: Siglo XX

Roy A (2016) What is urban about critical urban theory? Urban Geography 37(6):810-823

Sá H O (1977) Habitação: que política? Poder Local-Revista de Administração Democrática 3:34-37

Sá L (1978) Editorial. Poder Local-Revista de Administração Democrática 10:3

Salgueiro T B (2001) Lisboa, Periferia e Centralidades. Oeiras: Celta Editora

Schain M A (1985) French Communism and Local Power: Urban Politics and Political Change. London: Frances Pinter

Silva C N (1995) Autarquias locais e gestão do território. Que diferença faz o partido político? Finisterra - Revista Portuguesa de Geografia 30(59/60):99-120

Soares L B, Ferreira A and Guerra I (1985) Urbanização Clandestina na Área Metropolitana de Lisboa. Sociedade e Território 3:67-77

Stovall T (1990) The Rise of Paris Red Belt. Berkeley: University of California Press

Swyngedouw E (2009) The antinomies of the postpolitical city: In search of a democratic politics of environmental production. International Journal of Urban and Regional Research 33(3):601-620

Swyngedouw E (2011) Interrogating post-democratization: Reclaiming egalitarian political spaces. Political Geography 30:370-380 


\section{Please correct and return this set}

Please use the proof correction marks shown below for all alterations and corrections. If you wish to return your proof by fax you should ensure that all amendments are written clearly in dark ink and are made well within the page margins.

\begin{tabular}{|c|c|c|}
\hline Instruction to printer & Textual mark & Marginal mark \\
\hline Leave unchanged & ... under matter to remain & ( \\
\hline $\begin{array}{l}\text { Insert in text the matter } \\
\text { indicated in the margin }\end{array}$ & $h$ & $\begin{array}{l}\text { New matter followed by } \\
h \text { or } h \otimes\end{array}$ \\
\hline Delete & $\begin{array}{l}\text { I through single character, rule or underline } \\
\text { or }\end{array}$ & $\sigma$ or $\sigma / \otimes$ \\
\hline $\begin{array}{l}\text { Substitute character or } \\
\text { substitute part of one or } \\
\text { more word(s) }\end{array}$ & / through letter or & $\begin{array}{l}\text { new character / or } \\
\text { new characters / }\end{array}$ \\
\hline Change to italics & — under matter to be changed & $\leftarrow$ \\
\hline Change to capitals & $\equiv$ under matter to be changed & $\equiv$ \\
\hline Change to small capitals & $=$ under matter to be changed & $=$ \\
\hline Change to bold type & $\sim$ under matter to be changed & $\sim$ \\
\hline Change to bold italic & $\approx$ under matter to be changed & $\underline{s i n}$ \\
\hline Change to lower case & Encircle matter to be changed & $\not$ \\
\hline Change italic to upright type & (As above) & \\
\hline Change bold to non-bold type & (As above) & \\
\hline Insert 'superior' character & $\begin{array}{l}\text { I through character or } \\
K \text { where required }\end{array}$ & $\begin{array}{l}y^{\prime} \text { or } y \\
\text { under character } \\
\text { e.g. } y^{2} \text { or } y^{2}\end{array}$ \\
\hline Insert 'inferior' character & (As above) & $\begin{array}{l}\text { L } \\
\text { over character } \\
\text { e.g. } \hat{\imath}\end{array}$ \\
\hline Insert full stop & (As above) & $\odot$ \\
\hline Insert comma & (As above) & , \\
\hline Insert single quotation marks & (As above) & $\begin{array}{l}\dot{y} \text { or } \dot{X} \text { and/or } \\
\dot{y} \text { or } \dot{X}\end{array}$ \\
\hline Insert double quotation marks & (As above) & $\begin{array}{l}\ddot{y} \text { or } \ddot{y} \text { and/or } \\
\ddot{y} \text { or } \ddot{x}\end{array}$ \\
\hline Insert hyphen & (As above) & $1-1$ \\
\hline Start new paragraph & $\digamma$ & 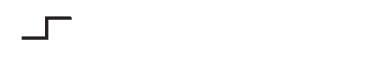 \\
\hline No new paragraph & $\infty$ & $\omega$ \\
\hline Transpose & $\sqcup$ & ᄃ \\
\hline Close up & linking $\bigcirc$ characters & \\
\hline $\begin{array}{l}\text { Insert or substitute space } \\
\text { between characters or words }\end{array}$ & $\begin{array}{l}\text { I through character or } \\
\Lambda \text { where required }\end{array}$ & \\
\hline $\begin{array}{l}\text { Reduce space between } \\
\text { characters or words }\end{array}$ & $\begin{array}{l}\text { between characters or } \\
\text { words affected }\end{array}$ & $\uparrow$ \\
\hline
\end{tabular}

